\title{
Versão eletrônica e outras mudanças
}

Com a publicação deste terceiro fascículo do volume 12 , Estudos de Psicologia está completando seu $12^{\underline{0}}$ ano como periódico científico, até aqui distribuído nos formatos impresso e eletrônico. A partir do volume 13, correspondente ao ano de 2008, Estudos de Psicologia passará a circular exclusivamente em versão eletrônica. ${ }^{1}$

Nesta oportunidade, cumpre agradecer o apoio recebido de nossos assinantes (individuais e institucionais), sem cuja contribuição Estudos de Psicologia não teria se firmado no patamar de qualidade que logramos, juntos, atingir. Nossa expectativa é de que esses parceiros no empreendimento juntamente com programas de pós-graduação, periódicos da área e outros órgãos, que recebiam nossos fascículos em regime de permuta ou doação - continuem a se beneficiar da produção veiculada nas "páginas" de nosso periódico. Nesse sentido, colocamos nosso endereço eletrônico (e-mail) à disposição dos interessados, para eventuais esclarecimentos e orientações porventura necessários para o acesso à versão eletrônica.

Gostaríamos, igualmente, de registrar nosso reconhecimento pelo apoio financeiro recebido do Programa Editorial do CNPq - nos últimos anos, acrescido da participação da CAPES -, esperando continuar contando com tal sustentação, imprescindível para a continuidade de nosso empreendimento, qualquer que seja o formato do suporte físico adotado.

A versão eletrônica de Estudos de Psicologia existe formalmente desde março de 2001, quando passou a integrar o acervo da SciELO (Scientific Electronic Library Online; http:// www.scielo.br/epsic), e ali continuará a servir aos interessados em busca e recuperação de sumários de fascículos, resumos/ abstracts e textos integrais dos artigos publicados. Reafirmamos o compromisso deste periódico com os ideais do livre acesso à produção científica arbitrada, já bastante preconizados por instituições várias e em documentos como a Declaração de Florianópolis (http://www.bvs-psi.org.br/DeclFlor.pdf), manifestação em favor do acesso aberto à literatura de pesquisa qualificada, aprovada por pesquisadores brasileiros reunidos no XI Simpósio de Intercâmbio Científico da ANPEPP (Associação Nacional de Pesquisa e Pós-graduação em Psicologia), em maio de 2006.

A veiculação de revistas científicas por meio eletrônico constitui tendência crescente, nacional e internacionalmente, ainda mais acelerada pelos recursos disponíveis na internet. $\mathrm{O}$ tradicional Psychological Abstracts (versão “em papel”), que foi durante alguns anos veiculado como PsycLIT, em formato de CDs trimestrais, atualmente se materializa como PsycINFO, poderosa ferramenta de informação bibliográfica disponível na internet, da qual Estudos de Psicologia faz parte.

Não é demais lembrar que o acesso ao PsycINFO pode ser feito pelo Portal de Periódicos da CAPES (http://www. periodicos.capes.gov.br/), que também disponibiliza mais de mil títulos de periódicos em texto integral que aquele Portal considera como relacionados a psicologia. São mais de 160 periódicos que contêm a expressão psycholog no título (psychology, psychologie, psychological, etc.), e 34 com psicolog (em língua portuguesa ou espanhola). Em que pesem as limitações do período de cobertura do acervo e as conhecidas desigualdades das condições de acesso a esses recursos na realidade brasileira, certamente é preciso reconhecer que - dentre as instituições acadêmicas e científicas já beneficiadas com esse acesso - raras seriam aquelas (se alguma) que poderiam disponibilizar um acervo desse porte, seja em formato impresso ou eletrônico.

$\mathrm{O}$ formato eletrônico tem sido cada vez mais valorizado em nosso meio; tanto que o relatório de 2007 da Comissão CAPES/ ANPEPP de Avaliação de Revistas reafirmou a exigência de "disponibilidade integral em endereços eletrônicos de acesso livre" como essencial para a atribuição de âmbito Nacional a um periódico brasileiro de Psicologia em avaliações futuras (http:// www.anpepp.org.br/index-aval.htm). Além da SciELO, que hospeda vários periódicos de Psicologia e áreas relacionadas, a comunidade brasileira passou também a contar, desde abril de 2005, com o Portal de Periódicos Eletrônicos em Psicologia - PePSIC (http://pepsic.bvs-psi.org.br/), que atualmente já disponibiliza mais de 50 títulos.

Outras mudanças em Estudos de Psicologia se referem à sua equipe.

Márcio Capriglione, que vinha fazendo parte da equipe desde o início, em 1996, deixa a editoria adjunta e a Revista, causando uma sensível lacuna, que vai implicar em mudanças na equipe de editores, a serem concretizadas durante o ano de 2008. Sucesso em seus novos empreendimentos, caro amigo! Ana Ludmila Costa, secretária da Revista e valiosa integrante de longa data da equipe, optou por buscar outros rumos profissionais, mas, antes de nos deixar definitivamente, ajudou sua sucessora no cargo, Keyla Amorim, a aprender os procedimentos do ofício.

Cumpre ainda registrar o lamentável falecimento de Álvaro Tamayo, professor na UnB por muitos anos e integrante do Conselho Científico desta Revista desde o primeiro número. Sua ausência será sentida na Revista e também no Programa de Pósgraduação em Psicologia da UFRN, pois a ambos engrandeceu com sua contribuição em diversas oportunidades. 
Antes de concluir, cabem agradecimentos: a nossos leitores, agentes fundamentais do sucesso desta Revista; aos autores, cuja confiança e participação são parte essencial do produto; e aos colegas avaliadores dos manuscritos submetidos (ver nominata anexa), garantia indispensável da qualidade dos trabalhos publicados.
Nas próximas páginas o leitor encontrará artigos de pesquisa e relatos de experiência cobrindo diversas áreas temáticas da Psicologia. Esperamos que sua leitura seja proveitosa.

José Q. Pinheiro Editor

${ }^{1}$ Os autores com produção prevista para edições futuras continuarão a dispor - como já acontece hoje, em nosso acervo de textos integrais na biblioteca SciELO - de arquivos em versão PDF (Portable Document Format, da Adobe Systems). Esse formato preserva a diagramação oficial da Revista, assegurando a qualidade não só do texto e suas divisões, mas também de tabelas e figuras, sendo o formato recomendado para distribuição/ circulação do material publicado. 